\title{
Resettlement and the environment in Vietnam: implications for climate change adaptation
} planning

Abstract: Increasingly the environment, and climate risks in particular, are influencing migration and planned resettlement in Vietnam, raising the spectre of increased displacement in a country already confronting serious challenges around sustainable land and water use and urbanisation. Planned resettlement has emerged as part of a suite of measures being pursued as part of disaster risk reduction and climate change adaptation strategies. This paper provides an historical, political, legal and environmental overview of resettlement in Vietnam identifying key challenges for framing resettlement as climate change adaptation. The paper outlines the scale of past resettlement in Vietnam, identifying the drivers and implications for vulnerability. Detailed case studies of resettlement are reviewed. Through this review, the paper reflects on the growing threat of climate change and the likelihood of increased displacement associated with worsening climate risks to identify some critical considerations for planned resettlement in climate change adaptation planning.

\section{Introduction}

People are on the move and are being moved due to environmental changes as both causal and proximate reasons for movement. The past decade has seen a rapid growth of research on the relationship between environmental change, human migration and population displacement. However, amongst the literature and case studies in this growing field of research, 'less attention has been given to planned relocations made necessary by the effects of climate change' (McAdam and Ferris, 2015: 137). Moreover, there is no clear consensus about whether planned relocation (termed here as resettlement) in anticipation of, or as a response to, climate change impacts can be

This is the author manuscript accepted for publication and has undergone full peer review but has not been through the copyediting, typesetting, pagination and proofreading process, which may lead to differences between this version and the Version of Record. Please cite this article as doi: $10.1111 /$ apv.12228

This article is protected by copyright. All rights reserved. 
considered adaptation (Barnett and O'Neill, 2011; McAdam and Ferris, 2015). Adaptation measures should decrease a population's vulnerability to harm and exposure to environmental or other risks (Smit and Wandell, 2006; Miller and Bowen, 2013). Yet, depending on the circumstances, resettlement processes can result in greater harm for people, especially those who lack access to viable livelihood assets and strategies, thus potentially undermining their capacity to cope with future shocks and stresses. This paper therefore seeks to explore whether planned resettlement can be considered adaptation in the context of responding to climate change impacts. It does so by drawing upon past examples of planned resettlement in Vietnam where major environmental transformations have occurred, such as those accompanying dam-related resettlement and urban renewal projects, and where environmental factors formed part of the impetus for population relocation. We conclude that planned resettlement in the context of climate change is primarily an expression of actual or inevitable "loss and damage", but is likely to play out under the guise of "adaptation". Turning to past examples of resettlement in Vietnam in light of emerging international mechanisms guiding states on how to better prevent and prepare for displacement, can help inform future decision making on planned resettlement and contribute to reducing the risk and likelihood of maladaptation.

Vietnam is considered to be amongst the top ten countries most at risk to climate change based on its exposure to both extreme weather events and potential sea-level rise (Dasgupta et al., 2007; Kreft et al., 2014). While the number of typhoons and tropical depressions in Vietnam are projected to decrease, strong to very strong typhoons are anticipated to increase (MONRE, 2016). Globally, Vietnam ranks fifth in terms of the proportion of the population living in Low Elevation Coastal Zones

This article is protected by copyright. All rights reserved. 
(LECZ) (McGranahan et al., 2006), meaning a large proportion of coastal dwellers will be exposed to extreme weather events such as typhoons and sea level inundation and face potential displacement. The most severe impacts are likely to occur in the Mekong and Red River deltas (Dasgupta et al., 2007). For example, the most recent assessment by the Vietnamese Ministry of Environment and Natural Resources (MONRE) indicates that approximately 39\% of the Mekong River Delta would be at risk of flooding from a one metre sea level rise (MONRE, 2016). Subsidence is also recognised as a significant threat (Anthony et al., 2015). The challenge of adaptation to climate change is therefore considerable.

The Vietnamese government considers resettlement to be among its key strategies for climate change adaptation (Chun, 2015). Indeed, Vietnam has a long history of government-initiated planned resettlement for political, economic and environmental reasons, as discussed below. Vietnam therefore provides a compelling case for exploring the challenges associated with resettlement as a form of climate change adaptation. Considering resettlement is playing a role in responding to climate change in the future, this paper seeks to identify what can be learnt from past experience with resettlement that might inform planning for future adaptation in ways that reduce vulnerability and ensure appropriate protections are in place. First, we provide a detailed review of the literature regarding the international policy context of migration, displacement and resettlement in the context of climate change. Next we provide an overview of the policy and legal context of resettlement in Vietnam before reflecting on secondary data about specific case studies of resettlement linked to environmental change. Our discussion then turns to analysing the implications of resettlement for climates change adaptation.

This article is protected by copyright. All rights reserved. 


\section{The international policy context of migration, displacement and}

\section{resettlement linked to climate change}

Over the past decade considerable attention on issues pertaining to people moving in the context of environmental change, especially those displaced by disasters and the effects of climate change, has emerged at the international policy level (McNamara et al., 2017). This offers some guidance for countries such as Vietnam in confronting the prospect of an increase in displacement in the future. After years of intransigence, a number of major international agreements across the areas of disasters, climate change, refugees and, more generally, sustainable development, that bring together national governments, the United Nations (UN) and other international actors, and civil society are beginning to concretely address the concerns associated with people who may have to move because of environmental changes. Despite this positive turn, much of this effort has focused on the issue of migration due to climate and other environmental changes, with planned resettlement in response to climate change (whether within or across international borders) remaining a poorly acknowledged and addressed area (de Sherbinin et al., 2011; McAdam and Ferris, 2015).

The emergence of international frameworks and mechanisms for protection of those displaced by climate change has its origins in work within the humanitarian sector, particularly in relation to disaster risk reduction and refugee protection. The humanitarian sector has long recognised the need to protect those who are internally displaced due to complex humanitarian disasters, with the articulation of guiding principles around clear norms concerning the treatment of people who are internally displaced first developed in 1998 (Guiding Principles on Internal Displacement, 2004). 
Although well recognised by governments and agencies around the world, they are not consistently adhered to and do not adequately recognise climate change as a driver of displacement.

For displacement of people across country borders the 1951 Refugee Convention remains the preeminent document, but so-called 'climate refugees' do not fall within its purview as is now well established (McAdam, 2012). The UN High Commissioner for Refugees' deliberations on climate change confirms the pre-eminence of focusing on existing humanitarian law and practices in dealing with people displaced by climate, noting: 'Protection concerns that arise in relation to climate related displacement need to be considered in the framework of existing international and regional laws and institutions' (UNHCR, 2011). Yet there is still a gap in protection for people who are forced to move across borders due to environmental change processes.

In recognition of this gap and the steady rise in numbers of those displaced by disasters (many of which are climate-related) (Gemenne, 2011;), the 2011 Nansen Conference sought to explicitly address protection for those displaced by disasters including the adverse effects of climate change (Nansen Conference, 2011). The Nansen Conference noted that,

\begin{abstract}
States have a primary duty to protect their populations and give particular attention to the special needs of the people most vulnerable to and most affected by climate change and other environmental hazards, including the displaced, hosting communities and those at risk of displacement. The development of legislation, policies and institutions as well as the investment of adequate resources are key in this regard (Nansen Conference, 2011: 5).
\end{abstract}

This article is protected by copyright. All rights reserved. 
The conference stressed that solutions to the problem of climate-related displacement need to be guided by a firm commitment to human rights, humanitarian norms, respect for human dignity and international cooperation (Nansen Conference, 2011: 14). This conference evolved into the multiagency Nansen Initiative which culminated in the endorsement, by over 100 governmental delegations in October 2015, of the Agenda for the Protection of Cross-Border Displaced Persons in the Context of Disasters and Climate Change (Nansen Initiative, 2015). This Protection Agenda represents some of the most comprehensive globally consultative work conducted in the arena of displacement linked to environmental change. It is being implemented by the Platform on Disaster Displacement (the follow-on multi-stakeholder platform of the Nansen Initiative, established in July 2016) and offers states a 'toolbox to better prevent and prepare for displacement before a disaster strikes, as well as to better respond to situations when people are forced to find refuge, within their own country or across an international border' (Platform on Disaster Displacement, n.d.: 2). Importantly, the Protection Agenda does not call for a new binding international convention on cross-border disaster displacement, but rather takes the approach of integrating 'effective practices by States and (sub-) regional organisations in their own normative frameworks in accordance with their specific situations and challenges' and 'seeks to complement and support, rather than duplicate' other relevant international and regional frameworks (Nansen Initiative, 2015: 7). Thus the Protection Agenda, together with the increased attention on displacement, including resettlement, in the context of disaster risk reduction in the Sendai Framework for Action on Disaster Risk Reduction (2015-2030) (UNISDR, 2015), the UN Framework Convention on Climate Change (UNFCCC), the UN 2030 Agenda for Sustainable Development and Global Compact for Safe,

This article is protected by copyright. All rights reserved. 
Orderly and Regular Migration ${ }^{1}$ represent positive signs that displacement in the context of natural disasters and climate change impacts is gaining the serious attention it demands.

The relevance of displacement being recognised in the above international agendas is that we are now closer to the establishment of a mechanisms for funds and resources to flow to countries to support populations who are displaced by the effects of climate change. The most consequential efforts taken to date that have the potential to tie action on climate-related displacement, both forced migration and resettlement, with available financial resources to support vulnerable countries fall within the UNFCCC. The 2015 Paris Agreement (ratified in 2016), which aims to enhance the UNFCCC's implementation and strengthen the global response to the threat of climate change, enshrined three key areas for addressing responses to climate change: mitigation, adaptation, and loss and damage. Climate financing under the UNFCCC, while complex, is likely to align according to these three categories. While adaptation has been consistently defined for over a decade as 'adjustment in natural or human systems in response to actual or expected climatic stimuli or their effects, which moderates harm or exploits beneficial opportunities' (McCarthy, Canziani et al., 2001: 982), loss and damage has no official or shared definition under the UNFCCC (Durand et al., 2016). Generally, loss and damage refers to 'negative effects of climate variability and climate change that people have not been able to cope with or adapt to' (Warner and Vandergeest, 2013: 369) or 'irreversible losses (e.g. loss of life, species, land) and costly damages (e.g. destroyed infrastructure) caused, at least in part, by climate change' (Durand et al., 2016: 2). There thus remains a tension between the UNFCCC's treatment of displacement as a form of "adaptation" or as

\footnotetext{
${ }^{1}$ Adopted by the UN General Assembly in December 2018, this document, a non-binding agreement, is "the first-ever negotiated global framework on a common approach to international migration in all its dimensions" (UN News, 2018).
}

This article is protected by copyright. All rights reserved. 
an example of "loss and damage". Specifically, of relevance to this paper, the question remains: is resettlement a form of 'adaptation' or evidence of 'damage and loss' due to climate change? This definitional issue is important in terms of countries' eligibility to access global climate change funds to finance resettlement schemes or support people to migrate with dignity. If resettlement is not considered "adaptation" then it may be considered something that should be funded under "loss and damage" mechanisms of UNFCCC, as discussed in the next section. Moreover, recognising resettlement as an example of "loss and damage" resists the normalisation of resettlement as an acceptable technical response to anticipated climate change effects, reinstating it as the option of last resort.

\section{Climate change "adaptation" versus "loss and damage"}

People displaced by development projects and related initiatives rarely experience improvements in their lives due to a decline in access to livelihood resources and opportunities, disruption of social and economic networks, and cultural impacts (Cernea, 1997; Scudder, 2011; Bui et al., 2013; OliverSmith and de Sherbinin, 2014). Whilst planned resettlement has long been a part of development projects (Wilks and Hildyard, 1994; Cernea, 2000; Scudder, 2011; Bennett and McDowell, 2012; Wilmsen and Webber, 2015) and disaster risk reduction interventions (Davis, 2007; Correa et al., 2011), it is only recently that migration and resettlement have been formally recognised as part of climate change adaptation.

Displacement due to climate change was not explicitly addressed in the UNFCCC in 1992 or the Kyoto Protocol of 1997; it was not until the UNFCCC sixteenth Conference of the Parties (COP 16) in

This article is protected by copyright. All rights reserved. 
Cancun during 2010 that migration and displacement were considered as part of adaptation

(Warner, 2011). Clause 14 (f) of the Cancun Adaptation Framework invited all Parties, in the context of their common but differentiated responsibilities and respective capabilities, and specific national and regional development priorities, objectives and circumstances, to undertake,

[m]easures to enhance understanding, coordination and cooperation with regard to climate change induced displacement, migration and planned relocation, where appropriate, at the national, regional and international levels (UNFCC, 2011).

A clear opportunity to address the issue of displacement arose several years later with COP21 in Paris. Paragraph 50 of the Agreement calls for a taskforce to be established, under the mandate of the Warsaw Mechanism for Loss and Damage, to investigate and 'to develop recommendations for integrated approaches to avert, minimize and address displacement related to the adverse impacts of climate change' (UNFCCC, 2015: para 49). Whilst an earlier draft of the COP21 Agreement had included reference to the establishment of a 'climate change displacement coordination facility' that would provide 'organised migration and planned relocation' (Milman, 2015), as well as compensation for people affected by climate change, the Warsaw Mechanism emerged as the preferred way forward.

Yet, it remains the subject of considerable debate as to whether displacement is a form of adaptation or evidence of harm and damage due to the impacts of climate change (see McNamara et al., 2018 for an excellent review). What is critical here in making such a determination is the

This article is protected by copyright. All rights reserved. 
circumstances under which a decision to move is taken, the degree of agency or coercion involved, the livelihood and wellbeing outcomes, and ultimately whether vulnerability to future climate risks is decreased. Adger et al. (2003) note, that whilst migration quite often reveals the limits of adaptation in place in the face of worsening conditions it also forms an essential adaptation strategy connecting people across places. When the outcomes of this population movement are positive, then it can be seen as a form of successful adaptation. Indeed, the influential UK Foresight (2011) study on migration and global environmental change stressed the positive possibilities of migration as a form of adaptation. However, for those who do not (or cannot) migrate, staying does not necessarily mean they are adapting well in place and may result in increased vulnerability compared with moving.

Resettlement is generally the option of last resort for communities and governments when staying in place means experiencing a deterioration in livelihood conditions and well-being, as well as potentially an increase in the loss of life. As evidenced by the considerable research undertaken on development-induced displacement (Scudder, 2011; Wilmsen and Webber, 2015) relocation always involves some "loss and damage", even if the motivation is to 'adapt' to climate change. McNamara et al. (2018) summarise these harmful effects as including loss or erosion of a sense of place and identity, self-efficacy, rights to land and culture, capital derived from physical places, and access to common property resources. These harmful effects are all likely to undermine a community's capacity to adapt to future climate risks. 
So, in light of the international efforts to establish clear norms and protections for people displaced by climate change, and consideration of resettlement in adaptation, the next section focuses on how such issues play out in the Vietnamese context through a review of the particular legal and political protections in place for those subject to resettlement.

\section{The national policy and legal context of resettlement in Vietnam}

Running in parallel to efforts to establish international norms and protections for people displaced across borders or internally displaced, Vietnam's efforts to clarify legal protections associated with resettlement have focused primarily on people's relations with land, specifically through land use laws and regulations. Prior to 1992, land was seen as entirely the domain of the state, so could be appropriated from households for development purposes without compensation (Dao, 2010). The Land Law in 1993 distributed land use rights to households as part of a wider process of loosening state control over production activities accompanying doi moi (renovation), as the economy transitioned from being centrally-planned to more market-oriented from the mid-1980s onwards. This led to official recognition of the state's responsibility to compensate people due forced land acquisition. The Land Law as well as the requirement for environmental impact assessments under the Environmental Protection Law (1993) have both contributed to improvements in resettlement practices (Dao, 2010). The revision of the Land Law in 2003 further strengthened the entitlement of compensation, extending this to those who may lack land titles (Singer et al., 2014). Further, The Constitution of the Socialist Republic of Viet Nam (2013) specifies that if the State needs to compulsorily purchase or requisition property for extreme cases such as 'for national defense or security reasons or ...in a state of emergency or in response to a natural disaster' the State must pay

This article is protected by copyright. All rights reserved. 
compensation at market price (Article 32) and where land is to be acquired for 'extreme necessity...or socio-economic development in the national or public interest' then 'Land recovery must be public and transparent, and compensation must be paid in accordance with the law' (Article 54) (National Assembly of the Socialist Republic of Vietnam, 2013). Whilst the land reforms of 1993 and 2003 brought benefits to land owners, however, one consequence has been the acceleration of land transfers and the rise of landlessness.

The increased presence of international financial donors, such as the Asian Development Bank, World Bank and others, has resulted in improvements in resettlement policy and practices in Vietnam, for instance through efforts to provide better support for people to re-establish their livelihoods after resettlement. Despite policy improvements, Vietnam appears reluctant to adhere to the relatively strict International Financial Institution (IFI) resettlement guidelines, including provisions for high compensation payouts, social and environmental impact assessment and information disclosure processes which add to project costs and complexity (Singer et al., 2014). Nonetheless, national regulations on resettlement (see Box 1) now stipulate higher levels of compensation than in the past, for example, 'land-for-land' compensation and livelihood assistance (Singer et al., 2014). Despite the gradual improvement of Vietnamese policies on resettlement over time and their relative conformity with IFI standards (Central Project Office, 2016) there remains a gulf between the policy intent and implementation (Dao, 2010; Ty et al., 2013, Singer et al., 2014; Singer and Watanabe, 2014). Moreover, the relatively high level of social protection and compensation mechanisms IFI's require, have also likely influenced the lack of major involvement of 
IFIs in recent years in resettlement intensive interventions, such as dam building (Middleton in Singer et al., 2014) and the major flood resettlement program discussed below.

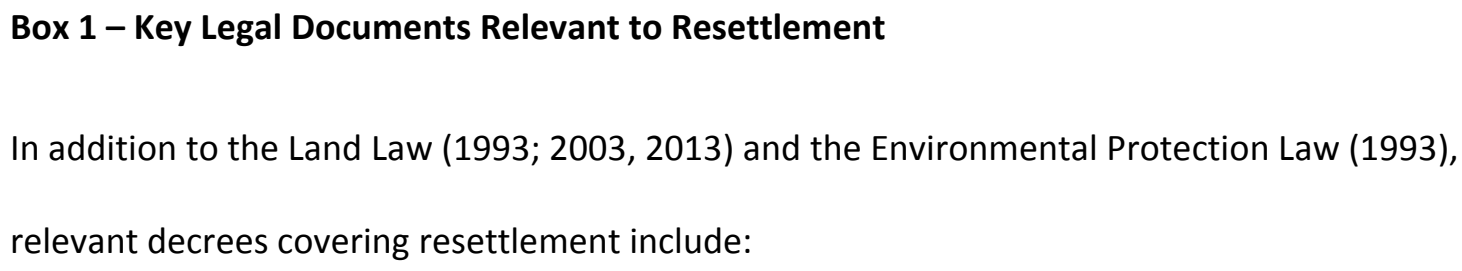

Decree No. 22/1998/ND-CP on compensation for damage when the state recovers land requires that the costs of compensation are born by the investor, yet local government has primary responsibility for implementation of resettlement programs (Dao, 2010).

Decree No. 197/2004/ND-CP supersedes the earlier decree (Decree No 22) and provides more detailed instructions on implementation of resettlement and recognition of the need for improved livelihood support for those displaced (Dao, 2010).

Decree No. 69/2009/QD-TTg further increased the level of compensation resettled people receive, reflecting the goal of resettlement leading to 'development' rather than just 'recovery'.

Decision No. 34/2010/QD-TTg laid out clear criteria for compensation for land loss due to irrigation and hydropower projects, and aims to guarantee improvements in quality of life for those resettled. It seeks to ensure those resettled have places to settle, can build a stable life with livelihood opportunities, can raise incomes and incrementally improve infrastructure. It also seeks to reduce potential conflict between resettled and host communities and introduces the principle of free and prior informed consent (Ty et al., 2013). 
Decree No. 44/2014/ND-CP and associated Circulars provide an updated method to determine land prices, and Decree No. 47/2014/ND-CP outlines updated compensation, assistance and resettlement procedures for land appropriated by the State (Central Project Office, 2016).

The Law on Cultural Heritage also stipulates the protection of cultural and historical vestiges, and the Law on Complaints (2011) and Decree No. 75/2012/ND-CP stipulating complaints and conflict resolution procedures (Central Project Office, 2016).

The peak government department responsible for state resettlement programs and migration is the Ministry of Agriculture and Rural Development (MARD). The Ministry of Labour, Invalids and Social Affairs (MOLISA) is primarily responsible for social matters concerning migration, with the Ministry of Public Security is responsible for household registration. These national level ministries are replicated at the provincial, district and commune levels, although national policies are subject to varied interpretation at the local level. It is not as yet clear what agency has lead responsibility for climate-related resettlement, as the Ministry of Environment and Natural Resources is responsible for climate change, yet in the case of flood-related resettlement, it is the Ministry of Construction together with MARD and provincial People's Committees that act as the lead agencies responsible for overseeing and planning resettlement (see below).

Ultimately however the success of resettlement often rests on the capacity and diligence of local authorities. Singer et al. (2014) note that it is local governments that have primary responsibility for resettlement and have largely been unable to restore living standards to pre-resettlement levels let alone improve outcomes. They observe that efforts by civil society groups and IFIs to improve outcomes of those resettled have been rather unsuccessful because, 
[t]he policy-praxis gap is glaring in Vietnam, particularly when legal provisions erode local government authority or elite benefits. Strong local resistance along with the central government's desire to maintain firm control of civil society has limited the scope of effective assistance in resettlement by external stakeholders (Singer et al., 2014: 98).

As such, despite improvements in legal protections for those resettled, there are major challenges associated with attaining positive outcomes for resettled communities due to capacity constraints at the local government level and political economic interests, as discussed through the examples below.

\section{Recent experience with environment-related resettlement in Vietnam}

This section presents a series of case studies of planned resettlement where major environmental transformations have occurred, such as those accompanying dam-related resettlement and urban renewal projects, and where environmental factors have formed part of the impetus for population relocation. Through the discussion of these case studies we wish to highlight key considerations for climate change adaptation planning where resettlement is involved in order to identify opportunities to minimise the potential for harm. The degree of agency affected individuals/households have in decision making, investment in livelihood support, and resulting levels of vulnerability to climate change are considered key in determining the outcomes of resettlement.

\section{Case study 1 - Dam-related resettlement}

The harmful social, economic, cultural and environmental impacts of resettlement due to large-scale development projects, such as dams, roads, pipelines and transmission lines, are well documented

This article is protected by copyright. All rights reserved. 
(McDowell, 1996; Cernea, 1997, 2000; Scudder, 2011, 2012; Bennett and McDowell, 2012). One of the most contentious development interventions is that of large dams. Dams have been a major driver of resettlement in Vietnam with hydropower central to the country's energy sector. For a relatively small country, Vietnam has a large number of rivers originating in or passing through its territory. Few of these rivers remain unaltered today, with most rivers dammed and diverted in the last 50 years in order to fully exploit their hydropower and water storage potential. Dao (2010) estimates some 1,967 reservoirs were built up until 2009. The three largest dams in Vietnam, Hoa Binh, Yali Falls and Son La, ' have led to the direct displacement of some 58,000, 6,000 and 91,000 people, respectively (Dao 2010; Bui et al. 2013), with an estimated 240,000 people in Vietnam resettled by dams overall (Ty et al. 2013). Overwhelmingly, the majority of the people resettled belong to ethnic minorities (Ty et al., 2013), often in circumstances where they had limited input in the decision making process.

Resettlement is expensive and the true costs are rarely factored into development projects. For instance, the Son La dam project was one of the first major projects in Vietnam to internalise the cost of resettlement, representing an estimated $29 \%$ of the total cost of the project (Dao, 2010). Because of this expense there is downward pressure to minimise compensation payments in terms of amount and eligibility. This reliance on financial compensation as the primary mechanism for addressing the impacts on communities, despite the goal of land-for-land swaps in Vietnamese law, has unsurprisingly been characterised by problems of inadequate payments. Lump-sum payments have also resulted in people investing in consumption rather than long-term production (Dao, 2010; Ty et al., 2013). So, despite many of the people subject to dam-related resettlement having legally 
recognised land rights, as a result of earlier land reforms, this has not translated into adequate protections and appropriate levels of compensation.

A survey undertaken by a national research institute found that $82 \%$ of dam-displaced people were worse off after resettlement compared with before (CODE cited in Singer et al., 2014). For instance, though the resettlement program for the Son La dam near Hanoi contained a 'land-for-land' compensation requirement for resettled and host communities, in fact this was difficult to achieve due to the lack of sufficient land available in the resettlement sites (Bui et al., 2013). Instead households received cash compensation, making the reestablishment of livelihoods near impossible. The increased attention on compensation, as required by legal changes outlined above, did however help both resettled and host community members with immediate food security needs following resettlement. However, a decline in the availability of productive assets likely threatens their longterm food, and livelihood, security (Bui et al., 2013).

So, it can be seen in the case of resettlement due to dams and also for purposes of poverty alleviation that the consequences have been highly uneven, with ethnic minorities greatly affected by such schemes. Pre-existing inequalities within and between communities have been exacerbated due to the poor livelihood outcomes of those resettled. Acknowledgement of the special needs of ethnic minorities in the areas of livelihood support and community institutions has been inadequate, reflecting the gulf between the intent of the policies summarised in Box 1 and the consequence of the resettlement schemes. 


\section{Case study 2 - Resettlement induced by urban renewal and upgrades}

In Ho Chi Minh City (HCMC), by the mid-1990s, rapid economic and industrial growth and the increasing influx of migrants associated with implementation of doi moi led to widespread pollution of and informal settlements encroaching along the city's vast network of canals and rivers (PMU 415, 2006). Consequently, the city government sought to tackle pollution and poverty challenges along the city's waterways (Anh et al., 2007). This led to the establishment of the 'Tan Hoa - Lo Gom Canal Sanitation and Urban Upgrading' project funded by a 20 million Euro grant from the Belgium government between 1998 and 2006 (PMU 415, 2006). The project, a cooperation between the People's Committee of HCMC and Belgian Technical Cooperation, was viewed as an experiment amongst a broader suite of donor projects tackling canal reshaping or slum upgrades (Anh et al., 2007).

Tan Hoa - Lo Gom Canal (THLM), a major canal, 7.6 kilometres in length and located in HCMC's west, was/is the city's most heavily polluted canal, owing to solid waste, sewerage and pollution from industrial and domestic wastewater being dumped directly in the canal (PMU 215, 2006; Anh et al. 2007). Its catchment area covers 19 square kilometres with a population of about 700,000 and by the mid-1990s informal settlements had built up along the canal edges. The broad project objectives were 'to improve the quality of life in the THLG canal area' and 'to strengthen the capacity of the communities and authorities dealing with pollution and urban poverty' (PMU 415, 2006). This particular project set out with a strong community participation mandate and adopted this approach throughout, via engaging social workers, for the key strategies through which it intended to address its objectives, namely: solid waste management; waste water treatment; canal improvement; 
institutional strengthening and capacity building; awareness raising and community participation; urban upgrading and resettlement; and socio-economic support (PMU 415, 2006).

Reflecting some of the fundamental principles referred to above, in terms of addressing the special needs of the most vulnerable, the resettlement component of this project included the specific objectives of:

- providing the poorest project affected households a resettlement solution adapted to their financial means and way of life;

- strengthening the capacity of the local community and authority in dealing with resettlement, socio-economic and environmental problems;

- evaluating different resettlement options (PMU 415, 2006).

The project adopted an evidenced-based and community-consultation-driven approach from the outset increasing the opportunity for people to shape the resettlement process. During the initial three-year phase of the project, a survey to understand the socio-economic characteristics and preferences of households living along a 300 metre stretch of the canal which would be widened leading to full or partial eviction was conducted (PMU 415, 2006). This provided the Project Management Unit (PMU) with a thorough understanding of the composition, characteristics and occupations of the dwelling households: the majority had resided in the area for a long period, were poor and worked as unskilled labourers or had micro-businesses. Importantly, through the survey process, the dwellers were given a chance to express what type of help they would need to restore 
their economic activities and their income in a sustainable way post-relocation. The survey participants expressed their strong preference for a market to be established in the resettlement area and support for accessing a stall at the market, their needs for vocational training, and their expectations that they would receive help to find a job or access credit for their businesses (PMU $415,2006)$. This survey highlighted strongly the importance of place and living arrangements for people's livelihoods. For example, relocating to a high-rise apartment dwelling would make it problematic for many to continue their livelihoods as these were largely played out in informal spaces at street level. Although land rights were ambiguous or absent, the right of consultation and compensation enshrined in law as a result of earlier land reforms strongly shaped the resettlement process. Perhaps most importantly, people were given a choice of resettlement options, including: a low-rise apartment block next to their former houses; resettlement to an area with basic infrastructure and plots 8 kilometres away to construct their own homes; or funds for self-relocation (PMU 415, 2006). Reflecting the centrality of place and networks to people's livelihoods, of these choices in-situ relocation was the preferred option. Finally, this case reveals the critical role community intermediaries can play, as owing to the 'active role of committed and patient social workers, no forced evictions took place' (Anh et al., 2007: 4).

\section{Case study 3 - Resettlement due to slow onset environmental change}

Aside from the future prospect of sea level rise the Mekong Delta is a site that presents many slow onset environmental changes, including riverbank erosion, subsidence, erosion from coastal storms, wave activity and regular flooding. The delta is where the water from the main stream of Mekong River spreads out over a large area of low elevation meaning that floods occur as a slow onset 
environmental change process in this part of Vietnam. Severe floods have been experienced in the Mekong Delta since the 1970s with flood impacts compounded by national scale de-urbanisation and population re-distribution policies between the mid-1970s to mid-1990s that saw the resettlement of over 6 million Vietnamese people to rural areas and New Economic Zones ${ }^{i i}$ (NEZs) (Zhang et al., 2006; Tuan 2014; Nguyen Dang Anh cited in Chun, 2015). This resulted in an increase in the number of people, infrastructure and production assets exposed to flood risk. From the late 1990s onwards, floods were a key development concern in the delta leading to a series of national government programs to promote socio-economic development, including Prime Ministerial Decisions No. 99/TTg and No. 173/2001/QD-TTg (Government of Vietnam, 1996, 2001). These decisions led to an overall strategy known as "living with the floods" involving the resettlement of some one million people in 200,000 households in the provinces of An Giang, Long An, Tien Giang, Vinh Long, Hau Giang, Can Tho City and Dong Thap from the severely flood-affected area of the delta to some 1,000 resettlement clusters and areas along dykes (Danh and Mushtaq 2011). The goal of the scheme, though not framed in relation to climate change, was that resettlement should ensure inhabitants have a 'safe and stable life' and do not need to evacuate when floods occur, whilst also creating favourable conditions for production activities and encourage agricultural industrialisation and modernisation (Government of Vietnam, 2001). The program targeted especially poor and landless households, with almost 20,000 landless and poor households in An Giang province alone to be relocated by 2020 (Dun 2011). In addition to supporting households with new houses on raised foundations the program also constructed additional infrastructure and services, extending electricity and drinking water supply systems. 
The program was implemented by local authorities with national government funding. Reflecting an issue with resettlement programs world-wide, there were problems with financial allocation and a lack of transparency at the local level (Chun, 2015). This contributed to the selection of unsuitable relocation sites, poor workmanship on house and foundation constructions, and problems with the feasibility and rationale of the programs' loan-centered structure (Chun, 2015). Chun also found problems with the way the target households were selected and a lack of community participation (2015). In addition to these tangible effects, Dun (2009) and Tuan (2014) recognised the role of social networks in mediating vulnerability and highlighted how the disruption to social networks associated with resettlement undermined the potential for people to re-establish their livelihoods in their new locality. Dun's (2009: 16) interviews with poor and/or landless households in An Giang province earmarked for potential resettlement to "residential clusters" only 1-2 kilometres away from their former residence showed the residents feared they would not be able to secure a daily income in their new location if they were 'moved further away from the wealthier inhabitants and landowners of the district' who employed them, loaned them money and upon whom they relied for their day-to-day income as wage labourers. Similarly Tuan's (2014) study with resettled households in Dong Thap showed the resettlement, while reducing direct exposure to floods, increased daily costs of living, led to loss of social networks and disrupted the income-earning activities of relocated households. The outcome for people has been mixed, with some people reporting improvements due to increased access to safe housing and services, such as schools and health clinics. The outcome is greatly influenced by whether people have been able to maintain or gain access to livelihood assets, particularly land for agriculture, aquaculture, or off-farm employment. 
Both Chun (2014) and Dun (2011) conclude from their studies that the resettlement scheme tended to shift rather than ameliorate vulnerabilities and, similar to the first case study presented in this paper, replicated pre-existing inequalities. Changes in livelihoods associated with relocation contributed to new vulnerabilities, such as:

- Increased distance from fields => income vulnerability

- Prohibition of livelihood activities (e.g., livestock) => income vulnerability

- Debt associated with government loans for plot and house construction => debt vulnerability

- Social networks disrupted => social disaggregation, isolation

- Increased dependence on government welfare => decline in self-reliance (Chun, 2014)

Similar to the dam-related resettlement case, Chun (2015) concludes that some households reported a decline in income and an increase in debt following relocation. Moreover, a change in flood patterns, due to flood control infrastructure, has resulted in a decline in the quality of land and other resources, undermining agriculture and fisheries livelihoods (Tuan 2014; Tran et al. 2018). This has thus made adaptation to future risks, in this climate vulnerable region, more challenging. So, whilst the intent of the 'living with the floods' program was to alleviate poverty and to move people out of harm's way, the significance of social networks in maintaining livelihoods, the lack of viable alternative livelihoods, and increase in debt have created new livelihood vulnerabilities (Dun 2009, 2011; Danh and Mushtaq, 2011; Chun, 2015). In responding to this new risk landscape some people have returned to their homes in the flooded zone whilst others have migrated (both temporally and permanently) to urban areas. 


\section{Discussion: Implications of resettlement for climate change adaptation}

\section{planning}

So, in light of the above analysis of international and national norms and protections that are in place for displaced people, and review of recent experience with environment-related resettlement, we wish to highlight four key implications for future adaptation planning.

\section{Resettlement is a part of climate change adaptation}

Resettlement continues to be a part of the government's socio-economic development policies (Chun, 2014) and has long been enshrined as a key objective in the National Strategy for Natural Disaster Prevention, Response and Mitigation to 2020 (Socialist Republic of Viet Nam, 2007). The Strategy aims to: 'Complete the relocation, arrangement and stabilization of the life for people in disaster prone areas' (Socialist Republic of Viet Nam, 2007: 4). The populations targeted for resettlement are those that are considered to be in disaster prone and border areas, highly disadvantaged, and those who are not permanently settled/registered in one location (Chun, 2015), and as such requires the state to take seriously its duty to protect as they are particularly vulnerable (Nansen Conference, 2011).

The government is now pursuing a range of options in response to climate risks, including: full protection, adaptation or full-withdrawal through resettlement (ISPONRE, 2009). Planned resettlement is currently being pursued in several projects, including one in southern Ca Mau province where 3000 households were relocated between 2006-2015, and a further 3000 are to be relocated by 2020 due to coastal erosion (Entzinger and Scholten, 2016). Early results indicate that there are some similar impacts for resettled households in Ca Mau as those experienced by floodresettled households in the upper delta (case study 3 above) e.g. loss of social networks and

This article is protected by copyright. All rights reserved. 
cohesion, increase daily living costs, and loss of livelihood for some community members (Ha and Tin 2015). However, the model of resettlement being applied in these cases is also ensuring resettlement sites are not located too far away from the sea and, thus, many of the inhabitants can continue their sea-based livelihoods despite living in a new location (Ha and Tin 2015). Additionally, resettled households have received improved infrastructure (health care, schools, transport and roads, electricity and trading facilities) and access to vocational education and skills training as part of the resettlement process ( $\mathrm{Ha}$ and Tin 2015). This is an indication of the shifting improvements that are occurring in resettlement projects in Vietnam over time.

Resettlement, though rarely the central focus, is quite often a consequence of the large-scale adaptation projects currently being pursued and can be expected to increase as the government mobilises climate change funds. Vietnam has recently announced some major investments in preparing for climate change in the Mekong Delta. The Mekong Delta Integrated Climate Resilience and Sustainable Livelihoods Project (P153544), which is co-led by MARD and MONRE, funded partially by the World Bank and costs US\$392,990,831, aims to strengthen climate resilient management and development across a range of sectors and seeks to improve land and water management practices, enhance climate-smart planning and invest in 'low-regrets' adaptive options (Central Project Office, 2016). These investments involve some resettlement, with a Resettlement Policy Framework in place for the first phase (Central Project Office, 2016), as part of the projects 'Managing Floods in the Upper Delta', 'Adapting to Salinity Transitions in the Delta Estuary', and 'Protecting Coastal Areas in the Delta Peninsula' (Central Project Office, 2016).

In addition to the restoration of mangrove belts, these projects involve rehabilitation or building of infrastructure to divert and control salt and fresh water flows in response to or anticipation of 
coastal erosion, sea level rise, and changing flood water and sediment levels (Central Project Office, 2016). It is not clear, however, the extent to which resettlement activities associated with such massive investments in adaptation, have learnt from the previous experience of household resettlement in Vietnam. Though the drivers were different for the three case studies reviewed here, there is a growing recognition amongst planners that the proximity of households to livelihoods and maintenance of social networks, as well as people's agency in the decision making process, are critical in determining the successful restoration of people's lives after resettlement. These points are certainly applicable to future planning for climate change induced resettlements.

\section{Resettled people face new, not reduced, vulnerabilities}

One of the greatest challenges associated with resettlement in a country such as Vietnam is the lack of suitable land for resettled communities - both for housing plots and production activities. In urban contexts, as with the Tan Hoa - Lo Gom Canal case discussed above, there is at least the option of vertical housing development, yet even here this constrains people's livelihood possibilities. This challenge is similarly faced by a number of countries around the world, particularly in densely populated agrarian countries such as Bangladesh, countries with large cities in the LECZ as well as small island nations.

Worsening climate risk is likely to exacerbate the already existing lack of suitable land for resettlement sites, further constraining the possibility of land-for-land swaps, communities staying together and people being able to continue past livelihood activities. The exposure of resettled

This article is protected by copyright. All rights reserved. 
households to new climate risks in settings they are not so familiar with, is also likely to undermine their capacity to restore their livelihoods to pre-resettlement levels.

The lack of suitable land is just one of the factors contributing to the creation of new vulnerabilities for people when they move. Whilst the reduction of exposure to environmental risks, whether pollution, floods, salinity intrusion or coastal erosion, increasingly forms the motivation for resettlement, resettled communities find themselves confronting new risks associated with debt, loss of income, and social dislocation, leading to new vulnerabilities and potentially new dependencies. As shown in the 'living with the floods' case, vulnerability did not decline but rather the profile shifted with resettlement. Only with a massive commitment to participatory planning and investment in livelihood support can vulnerabilities be reduced, as shown by the Tan Hoa - Lo Gom Canal case. Key here is ensuring communities have agency in the decision-making process.

Resettlement involves loss and damage that can only partially be ameliorated through compensation

Documented problems associated with resettlement in Vietnam reflect many of the impoverishment risks seen in other settings and accord with understandings of what constitutes "loss and damage", in terms of 'irreversible losses (e.g. loss of life, species, land) and costly damages (e.g. destroyed infrastructure)' (Durand et al. 2016: 2). 
From a loss and damage point of view, the most acute impacts of resettlement concern the loss of income, employment and livelihood opportunities, and the disruption of the social and economic networks that maintain these. Moreover, the loss or simplification of the suite of resources required to maintain a livelihood, such as different land parcels, forests, wetlands and fisheries, can also have devastating impacts (Bui et al. 2013, Ty et al. 2013, Singer et al. 2014). There are other less tangible ways in which harm and loss can be experienced by resettled communities, including the exacerbation of inequalities (Bui et al. 2013; Chun 2014), rise in tensions and conflicts within and between resettled and host communities, and the cultural impacts associated with loss of attachments to place, familiar ways of life and community cohesion - all of which undermine people's well-being. Where loss and damage can not be compensated, policy must recognise the pivotal role of those directly affected in determining appropriate redress schemes, such as retraining schemes, museums, memorials as well as documentary efforts.

Although getting appropriate and transparent compensation in place has been the focus of the past few decades of legal reforms concerning resettlement in Vietnam, and elsewhere, the losses and damages associated with resettlement can only partially be ameliorated through compensation. This is particularly apparent when it comes to intangible impacts, such as impacts on culture, attachment to place and community cohesion. Even if the much-anticipated global climate finance materialises, this will only partly offset the harm of resettlement.

This article is protected by copyright. All rights reserved. 
Capacity and commitment of local government greatly determines resettlement outcomes

Finally, poor resettlement outcomes are compounded by capacity constraints at the local government level, particularly in regards to facilitating the participation of affected communities in planning processes (Dao, 2010; Singer et al. 2014). This is borne out in our case studies, where the Tan Hoa - Lo Gom Canal project's investment in participatory planning and involvement of community intermediaries increased opportunities for people's control over the process, avoiding forced evictions. This is in contrast to the other examples of resettlement discussed above where a lack of capacity at the local government scale seriously undermined the success of the projects.

Improving the capacity of local government to plan resettlement projects, and adaptation more generally, in more consultative and participatory ways, can increase the agency people have in the process, increasing the chance that housing and livelihood support is more appropriate and effective.

\section{Conclusion}

This paper sought to address the question: what can be learnt from past experience with resettlement that might inform planning for future adaptation in ways that reduce vulnerability and ensure appropriate protections are in place? We conclude that although the intent of resettlement schemes may be development, poverty alleviation and vulnerability reduction, unintended consequences include the creation of new environmental, social and economic risks for resettled

This article is protected by copyright. All rights reserved. 
people. These risks are likely to be compounded by additional threats to livelihoods, infrastrucutre and lives accompanying climate change, although it is important to acknowledge new risks (for example associated with health) are also likely to emerge.

There has been considerable progress internationally and nationally in articulating clear norms and principles regarding the protection of people displaced by climate and other environmental stresses. As much displacement continues to be internal, however, national level mechanisms for ensuring human rights and the most vulnerable are protected are highly consequential. Vietnam continues to demonstrate commitment to improving protections for people who are resettled, with much of these efforts focused on respecting land rights and improving compensation procedures. More support for local-level government to undertake participatory planning and identify and support (especially vulnerable) people with appropriate and effective livelihood support is a critical priority in light of the likelihood of increased resettlement due to climate risks in the future.

Whilst international mechanisms for protecting the rights of people displaced (internally and internationally) by disasters and climate change are slowly taking shape, the possibility of neatly fitting displacement into either an "adaptation" or "loss and damage" category for the purposes of accessing climate finance and resources remains elusive (as does the flow of climate finance). We argue here that, based on evidence from Vietnam, that it is more appropriate to consider planned resettlement linked to the effects of climate change as an articulation of or evidence of (actual or inevitable) loss and damage, even though it will likely play out under the guise of (planned) adaptation based on the need for relocation to occur before the full extent of loss and damage completely takes hold. Recognising resettlement as evidence of "loss and damage" elevates 
attention on the seriousness of the impacts of resettlement and resists the normalisation of resettlement as anything other than the option of last resort.

Where resettlement occurs specifically due to climate change, it is likely to be maladaptive due to the considerable losses (e.g. of access to land and common property resources, social networks, livelihoods) and damages that result (Barnett and O'Neill, 2011; McMichael et al., 2012; Adger et al., 2012). Even those making the case that planned resettlement is adaptation admit that it is not the case for all those involved and for some groups it is maladaptive (Lei et al., 2017). A key aspect determining the extent of adverse outcomes of the relocation process hinges on the voluntary nature of relocation efforts (Barnett and O'Neill, 2011; Lei et al., 2017). It is perhaps with increasing voluntariness and community control over the decision-making process (when, how, where, who, and what) that provides some potential for planned resettlement to shift towards the adaptation end of the spectrum.

\section{References}

Adger, W. N., et al. (2003). "Adaptation to climate change in the developing world." Progress in development studies 3(3): 179-195.

Adger, N.W.; Barnett, J.; Brown, K.; Marshall, N.; O’Brien, K. (2012) ‘Cultural dimensions of climate change impacts and adaptation' Nature Climate Change 3(2): 112-117.

This article is protected by copyright. All rights reserved. 
Anh, L.D.; Legrand, B.; Van Lint, J. (2007) 'Tan Hoa Lo Gom: Building a new life' Paper presented at $43^{\text {rd }}$ ISOCARP (International Society of City and Regional Planners) Congress, Antwerp, Belgium, 19-23 September. Retreived from: http://www.isocarp.net/Data/case studies/1028.pdf

Anthony, E. J., Brunier, G., Besset, M., Goichot, M., Dussouillez, P., \& Nguyen, V. L. (2015). Linking rapid erosion of the Mekong River delta to human activities. Scientific Reports, 5: 14745.

Barnett, J. and S. J. O'neill (2011). "Islands, resettlement and adaptation." Nature Climate Change 2(1): 8 .

Bennett, O. and C. McDowell (2012). Displaced The Human Cost of Development and Resettlement, Palgrave.

Bui, T. M. H., et al. (2013). "Hydropower development in Vietnam: Involuntary resettlement and factors enabling rehabilitation." Land Use Policy 31: 536-544.

Central Project Office (2016) 'Mekong Delta Integrated Climate Resilience and Sustainable Livelihoods Project (MD-ICRSL): Resettlement Policy Framework'. Hanoi: Ministry of Agriculture and Rural Development.

Cernea, M. (1997). "The risks and reconstruction model for resettling displaced populations." World Development 25(10): 1569-1587.

Cernea, M. M. (2000). "Risks, safeguards and reconstruction: A model for population displacement and resettlement." Economic and Political Weekly: 3659-3678.

Chandola, H. (1977) ‘New Economic Zones’ Economic and Political Weekly, 12(4): 83-85. 
Chun, J. M. (2014). Livelihoods under stress: household assets and responses to environmental change in the Mekong Delta, Vietnam, University of Oxford.

Chun, J. M. (2015). Planned Relocations in the Mekong Delta: A successful model for climate change adaptation, a cautionary tale, or both? Brookings LSE Project on Internal Displacement. Washington DC, Brookings Institution.

Correa, E., et al. (2011). Populations at Risk of Disaster: a resettlement guide. Washington, World Bank.

Danh, V. T. and S. Mushtaq (2011). Living with floods: an evaluation of the resettlement program of the Mekong Delta of Vietnam. Environmental change and agricultural sustainability in the Mekong Delta, Springer: 181-204.

Dao, N. (2010). "Dam development in Vietnam: The evolution of dam-induced resettlement policy." Water Alternatives 3(2): 324.

Dasgupta, S., Laplante, B., Meisner, C., Wheeler, D., and Yan, J. (2007) The Impact of Sea Level Rise on Developing Countries: A Comparative Analysis. World Bank Policy Research Working Paper Series 4136. Washington D.C.

Davis, I. (2007). Learning from Disaster Recovery Guidance for Decision Makers Geneva and Kobe, A Publication from the International Recovery Platform (IRP) Supported by the Asian Disaster Reduction Center (ADRC), International Strategy for Disaster Reduction (ISDR) secretariat and United Nations Development Programme (UNDP).

This article is protected by copyright. All rights reserved. 
de Sherbinin, A., et al. (2011). "Preparing for resettlement associated with climate change." Science 334(6055): 456-457.

Dun, O. (2009). Linkages between flooding, migration and resettlement: Viet Nam case study report for EACH-FOR Project. Bonn, Germany: United Nations University Institute for Environment and Human Security. Available at:

http://ro.uow.edu.au/cgi/viewcontent.cgi?article=2409\&context=sspapers

Dun, O. (2011). "Migration and displacement triggered by floods in the Mekong Delta." International Migration 49(s1): e200-e223.

Durand, A.; Hoffmeister, V.; Weikmans, R.; Gewirtzman, J.; Natson, S.; Huq, S.; Timmons Roberts, J. (2016) 'Financing Options for Loss and Damage: a Review and Roadmap' DIE Discussion Paper 21/2016. Deutsches Institut für Entwicklungspolitik (DIE)/German Development Insitute: Bonn. https://www.die-gdi.de/uploads/media/DP 21.2016.pdf

Entzinger, H. and Scholten, P. (2016) Adapting to Climate Change through Migration: A Case study of the Vietnamese Mekong Delta, Geneva: IOM.

Foresight: Migration and Global Environmental Change. (2011). Final Project Report. London: The Government Office for Science.

Gemenne, F. (2011). "Why the numbers don't add up: A review of estimates and predictions of people displaced by environmental changes." Global Environmental Change 21: S41-S49.

This article is protected by copyright. All rights reserved. 
Government of Vietnam (1999). Prime Minister Decision No. 99/1996/QD-TTg - Longterm

Orientation and Five Year Plan of 1996-2000 for the Development of Water Resources,

Transportation and Rural Development in the Mekong Delta. Hanoi, Vietnam.

Government of Vietnam (2001). Prime Minister Decision No. 173/2001/QD-TTg - Decision on Socio-

Economic Development in the Mekong River Delta Region in the 2001-2005 Period. Hanoi,

Vietnam.

Guiding Principles on Internal Displacement (2004). Guiding Principles on Internal Displacement (second edition). http://www.unhcr.org/43ce1cff2.html, United Nations Organisation for Coordination of Humanitarian Affairs.

Ha, T. T. P. and Tin, N. H. (2015) 'Draft Report on Household Survey and Key Informant interviews in Viet Nam's Mekong Delta for the EU-funded project 'Migration, environment and climate change: Evidence for policy (MECELP)', Can Tho: Can Tho University.

ISPONRE (2009). Viet Nam Assessment Report on Climate Change, Hanoi: Institute of Strategy and Policy on natural resources and environment, Viet Nam.

Kreft, S., et al. (2014). Who Suffers Most From Extreme Weather Events? Weather-related Loss Events in 2013 and 1994 to 2013. Briefing Paper Global Climate Risk Index 2015. Bonn, Germanwatch.

Lei, Y.; Finlayson, C. M.; Thwaites, R.; Shi, G.; Cui, L. (2017) 'Using Government Resettlement Projects as a sustainable adaptation strategy for climate change' Sustainability 9(8): 1373 doi:10.3390/su9081373

This article is protected by copyright. All rights reserved. 
McAdam, J. (2012). Climate change, forced migration, and international law, Oxford University Press.

McAdam, J. and E. Ferris (2015). "Planned relocations in the context of climate change: unpacking the legal and conceptual issues." Cambridge J. Int'l \& Comp. L. 4: 137.

McCarthy, J.J.; Canziani, O.F.; Leary, N.A.; Dokken, D.J.; and White, K.S. (2001) Climate Change 2001: Impacts, Adaptation, and Vulnerability. Contribution of Working Group II to the Third Assessment Report of the Intergovernmental Panel on Climate Change (IPCC). IPCC: Cambridge University Press. https://www.ipcc.ch/ipccreports/tar/wg2/index.htm

McDowell, C. (1996). Understanding impoverishment: The consequences of development-induced displacement, Berghahn books.

McMichael, C.; Barnett, J.; McMichael, A.J. (2012) 'An Ill wind? Climate change, migration, and health' Environmental Health Perspectives 120(5): 646+

McNamara, K. E. (2007). "Conceptualizing discourses on environmental refugees at the United Nations." Population and Environment 29(1): 12-24.

McNamara, K., et al. (2017). "Environment and migration experts: Who are they, and what are their views?" Migration, Environment and Climate Change: Policy Brief Series 3(2): 1-10.

McNamara, K. E., et al. (2018). "The complex decision-making of climate-induced relocation: adaptation and loss and damage." Climate Policy 18(1): 111-117.

McGranahan, G., D. Balk, and B. Anderson. 2006. "Low coastal zone settlements." Tiempo - A bulletin on climate and development 59:23-26.

This article is protected by copyright. All rights reserved. 
Miller, F. and Bowen, K. (2013) Questioning the assumptions: the role of vulnerability assessments in climate change adaptation, Impact Assessment and Project Appraisal, 31:3, 190-197, DOI: $10.1080 / 14615517.2013 .819724$

Milman, O. (2015). UN drops plan to help move climate-change affected people. The Guardian.

MONRE 2016 'Climate change and sea level rise scenarios for Viet Nam' Hanoi: MONRE

Nansen Conference (2011). The Nansen Conference: Climate Change and Displacement in the 21st Century, Oslo, Norway, Norwegian Refugee Council. http://www.unhcr.org/4ea969729.pdf

Nansen Initiative (2015). Agenda for the protection of cross-border displaced persons in the context of disasters and climate change. Volume I. Geneva, Switzerland, Nansen Initiative.

National Assembly of the Socialist Republic of Vietnam (2013) 'The Constitution of the Socialist Republic of Viet Nam' English language version available at: http://vietnamnews.vn/politicslaws/250222/the-constitution-of-the-socialist-republic-of-viet-nam.html

Oliver-Smith, A. and A. de Sherbinin (2014). "Something Old and Something New - Resettlement in the twenty-first century." Humanitarian Crises and Migration: Causes, Consequences and Responses: 243.

Platform on Disaster Displacement n.d. Addressing the protection needs of people displaced across borders in the context of disasters and climate change. Platform on Disaster Displacement: Geneva. https://disasterdisplacement.org/the-platform/our-response

This article is protected by copyright. All rights reserved. 
PMU (Project Management Unit) 415 (2006) 'Bilateral development cooperation between the governments of Belgium and Vietnam to improve the quality of life in the Tan Hoa Lo Gom Canal Basin'

Scudder, T. (2011). "Development-induced community resettlement." New Directions in Social Impact Assessment. Cheltenham: Edward Elgar Publishing Limited.

Scudder, T. T. (2012). The Future of Large Dams:" Dealing with Social, Environmental, Institutional and Political Costs", Taylor \& Francis.

Singer, J., et al. (2014). "Broadening stakeholder participation to improve outcomes for dam-forced resettlement in Vietnam." Water Resources and Rural Development 4: 85-103.

Singer, J. and T. Watanabe (2014). "Reducing reservoir impacts and improving outcomes for damforced resettlement: experiences in central Vietnam." Lakes \& Reservoirs: Research \& Management 19(3): 225-235.

Smit B. and Wandel J.(2006). Adaptation, adaptive capacity and vulnerability. Global Environmental Change. 16(3):282-292.

Tran, D.D., van Halsema, G., Hellegers, P.J., Ludwig, F., and Wyatt, A. 2018. Questioning triple rice intensification on the Vietnamese mekong delta floodplains: An environmental and economic analysis of current land-use trends and alternatives. Journal of Environmental Management, 217, 429-441.

This article is protected by copyright. All rights reserved. 
Tuan, V. V. (2014) "Vulnerability Assessment of Different Socio-Economic Groups to Floods in the rural Mekong Delta of Vietnam", Doctoral thesis. Bonn: Rheinischen Friedrich-WilhelmsUniversität Bonn. Retreived from: http://hss.ulb.uni-bonn.de/2014/3509/3509.pdf

Ty, P. H., et al. (2013). "Compensation and resettlement policies after compulsory land acquisition for hydropower development in Vietnam: policy and practice." Land 2(4): 678-704.

UNFCCC (2011). Report of the Conference of the Parties on its sixteenth session, held in Cancun from 29 November to 10 December 2010, United Nations Framework Convention on Climate Change.

UNFCCC (2015). Conference of the Parties Twenty-first session Paris, 30 November to 11 December 2015, United Nations Framework Convention on Climate Change.

UNHCR (Office of United Nations High Commissioner for Refugees) (2011). Summary of Deliberations on Climate Change and Displacement, Bellagio, Italy, UNHCR.

UNISDR (2015). Sendai Framework for Disaster Risk Reduction 2015-2030. Geneva, UNISDR.

UN News (2018) “General Assembly officially adopts roadmap for migrants tim improve safety, ease suffering", New York, United Nations, 19 December, https://news.un.org/en/story/2018/12/1028941

Warner, K. (2011) “Climate Change Induced Displacement: Adaptation Policy in the Context of the UNFCCC Climate Negotiations" UNHCR Legal and Protection Policy Research Series No. 18 (PPLA/2011/02). New York, United Nations High Commissioner for Refugees (UNHCR).

This article is protected by copyright. All rights reserved. 
Warner, K. and Vandergeest, K. (2013) 'Loss and damage from climate change: local-level evidence from nine vulnerable countries', International Journal of Global Warming, 5(4): 367-386).

Wilks, A. and N. Hildyard (1994). "Evicted! The World Bank and Forced Resettlement." The Ecologist 24(6): 225-229.

Wilmsen, B. and M. Webber (2015). "What can we learn from the practice of development-forced displacement and resettlement for organised resettlements in response to climate change?" Geoforum 58: 76-85.

Zhang, H. X., et al. (2006). "Migration in a transitional economy: Beyond the planned and spontaneous dichotomy in Vietnam." Geoforum 37(6): 1066-1081.

\footnotetext{
'Construction phases for the dams were Hoa Binh: 1979-1994, Yali Falls: 1993-2001, and Son La: 2005-2013.

ii NEZs were mainly in rural areas where the government reclaimed land damaged by war or established new areas to resettle people who had been displaced to the cities during the Vietnam/American war, whose villages had been destroyed, who no longer had jobs in the city and who could be absorbed into agriculture (Chandola, 1977).
} 
Resettlement and the environment in Vietnam: implications for climate change adaptation planning

Fiona Miller ${ }^{1}$ and Olivia Dun ${ }^{2}$

${ }^{1}$ fiona.miller@mq.edu.au (corresponding author) Department of Geography and Planning, Macquarie University, NSW 2109, Australia

${ }^{2}$ School of Geography, The University of Melbourne, Victoria 3010, Australia/School of Geography and Sustainable Communities, University of Wollongong, NSW 2522, Australia

\section{Acknowledgements}

Fiona Miller would like to gratefully acknowledge funding provided by Macquarie University's Outside Studies Program and the Gothenburg University School of Global Studies visiting research program for enabling her time to work on this paper. Olivia Dun is very grateful for the Tempe Mann Travelling Scholarship provided by the Australian Federation of Graduate Women, an Australian Postgraduate Award provided by the University of Sydney, and the Environmental Change and Forced Migration Scenarios (EACH-FOR) project (ID: 44468 - funded by the European Commission Sixth Framework Programme) for funding her research work in Vietnam. We also gratefully acknowledge the constructive comments of the two anonymous reviewers.

This article is protected by copyright. All rights reserved. 


\section{University Library}

\section{- M M N E R VA A gateway to Melbourne's research publications}

Minerva Access is the Institutional Repository of The University of Melbourne

Author/s:

Miller, F;Dun, O

Title:

Resettlement and the environment in Vietnam: Implications for climate change adaptation planning

Date:

2019-07-22

Citation:

Miller, F. \& Dun, O. (2019). Resettlement and the environment in Vietnam: Implications for climate change adaptation planning. ASIA PACIFIC VIEWPOINT, 60 (2), pp.132-147. https:// doi.org/10.1111/apv.12228.

Persistent Link:

http://hdl.handle.net/11343/286898 